half a dozen of the finest universities in the United States. The subject, it seems, is dying out on campus because it has echoes of elitism — and worse, racism - that make students and university officials uncomfortable.

This is a distortion that contributes to widespread and wrong ideas about intelligence and the motives of those who study it. This is especially true when it comes to the genetics of intelligence, a meta-analysis of which is published online this week in Nature Genetics (S. Sniekers et al. Nature Genet. http://dx.doi.org/10.1038/ng.3869; 2017).

The research pools together genome-wide association studies looking at a total of nearly 80,000 children and adults. The studies used different measures of "general intelligence", including IQ scores and number of correct answers given to brief touchscreen puzzles. The meta-analysis identifies 18 genomic regions associated with intelligence, and candidate genes that are highly expressed in the brain. The associations, the study suggests, could explain up to $4.8 \%$ of the variance in intelligence across these cohorts.

It's the latest in a series of studies to probe the details of how genetics influences cognitive ability. Note the word 'how'. For, despite claims to the contrary - some well meaning and some merely ignorant - it's well established and uncontroversial among geneticists that together, differences in genetics underwrite significant variation in intelligence between people. It's just that those differences seem to be many and of little consequence by themselves. As such, intelligence is a classic polygenic human trait - just like many other cognitive and physical features, from mental disorders to height.

So why the controversy? Why are psychology undergraduates denied tuition in what is surely one of the most central and influential human traits? Perhaps unusually for a field of science, the biggest obstacles to research on, and broader understanding of, intelligence lie not ahead, but in the past.

There seem to be three. The first, and the most easily addressed, is misplaced fear about biological determinism: some worry about the idea that if certain genes are influential in intelligence, individuals

without them cannot be bright and successful. Yet that is not so environment is crucial, too. The existence of genes 'for' intelligence would not imply that education is wasted on people without those genes. Geneticists burned down that straw man long ago.

The second obstacle is a hazard of timing as much as anything. Intelligence science and testing first flourished as twentieth-century concerns over immigration hardened into policies to protect the genetic

Some critics fear that research on the genetics of intelligence - any research - will fan these ugly flames of the past. aims of the racial superiority of white people. More recently, the (genuine but closing) gap between the average IQ scores of groups of black and white people in the United States has been falsely attributed to genetic differences between the races.

Some critics fear that research on the genetics of intelligence - any research - will fan these ugly flames of the past and could be used for dubious purposes in the future. Certainly, the undesirable attitudes that gave intelligence science its bad reputation remain, and pockets of dubious research continue. But intelligence science need not be held back by its past.

As study after study is showing, the genetic variation between individuals and its influence on traits is more complex and subtle than scientists realized even at the start of this century. The more that researchers probe traits such as intelligence, and show how there is no genetic basis for discrimination, the more they distance themselves from the mistakes of the past. What most people know about intelligence must be updated.

\section{Eclipsed by the Sun} Nature won't repeat the mistake of its founding editor for this summer's solar totality.

$\mathrm{I}$ $\mathrm{n}$ an Editorial written in these pages in January 1900, the editor of Nature took the unusual step of describing something that bugged him. More, he listed the singular moment, almost 30 years previously, when he had "never felt more annoyed in my life".

Norman Lockyer, this journal's founder and original editor, was fascinated by solar eclipses. And he knew that others were, too. So when he asked a Captain Bailey of the Royal Engineers, who had travelled 400 miles to help observe an eclipse in India, to time the event, Lockyer was horrified to see the man deliberately turn his chair to face away from the Sun to focus on the task. The man from the military missed the 1871 show, and all because of Lockyer's self-confessed "ignorance of eclipse organisation".

No editor of Nature will make that mistake again. So, in plenty of time, this week we offer readers the first official notification that chairs must be turned to face the correct way on 21 August. That's when the shadow of a total solar eclipse will race across a broad corridor of the continental United States. And in a Books and Arts piece, Jay Pasachoff, whets the appetite with a review of four new books pegged to what he calls "the most stupendous sight in nature". Some 12 million people across 14 US states live beneath the direct path of the summer totality, and millions more are expected to make the trip to see it.
Among the historical eclipses discussed in the review - from cloudy Cornwall in 1999 to ancient Babylonia — is the notable presence at an 1878 observation in Wyoming of a young Thomas Edison. (Who, of course, would help to launch his own celebrated journal a couple of years later.) Edison had brought a self-designed instrument to measure heat from the Sun's corona. Lockyer was there, too. And the editor of Nature was impressed with the "wonderful instrument" built by the founder of Science. "It is quite possible that he may succeed in his expectations," Lockyer wrote in a report from the site two days before the eclipse. But, in an astute early peer review, he also observed: "The instrument, however, is so young, that doubtless there are many pitfalls to be discovered."

In the century or so that has followed, scientists have been among the keenest observers of solar eclipses, which offer a rare chance to study the impact of the unusual resulting conditions on everything from the atmosphere to the efficiency of solar panels. And, like Captain Bailey, at least some of this work involves not looking at the sky at the time. Biologists, for example, have watched how tropical tent-web spiders (Cyrtophora citricola) take down their webs during a totality and then rebuild them when the sun reappears.

Lockyer learnt from his guilt about the backwards-sitting Captain Bailey. At future eclipses, he changed his planning and shared the timekeeping duties between two people - one of whom would always face the correct way. With military precision, he got them to swap places half-way through. And to help the army of volunteers time the operation of the bulky telescopes they had brought, Lockyer arranged for a bugler to sound a series of blasts (always on the note $G$ ) to mark the countdown from seven minutes to just five seconds before totality.

Eighty-eight days remain before the next one. Consider yourselves well and truly alerted. It's what Norman would have wanted. 